\title{
Business managers in children's playground: Exploring a problematic (or not!) identity construction of early childhood teachers in New Zealand
}

\section{Olivera Kamenarac}

Te Kura Toi Tangata School of Education, University of Waikato, Hamilton, New Zealand E-mail: olivera.kamenarac@waikato.ac.nz

\begin{abstract}
The impacts of neo-liberal education reforms on the early childhood education sector have been a focal point of scholarly critiques in New Zealand. Interestingly, only a few studies have addressed how teacher professional identities and professionalism have changed in response to the neoliberal context of New Zealand early childhood education. It has been, however, recognised that understanding the complexity of teacher professional identities within the rapidly transforming landscape of early childhood education is a key consideration in implementing and sustaining a change agenda in education policies and practices. In this article, the author draws on data from her research study about how teachers' professional identities have been reconstructed in response to the shifting discourses in New Zealand early childhood education policies and practices. Specifically, the author explores the construction of teachers as business managers, which has emerged through an interplay of discourses of marketisation and privatisation driving some of the country's early childhood education policies and practices. It is argued that the construction of teachers as business managers has altered core professional ethical values underpinning the teaching profession, professionalism and the purpose of early childhood education in New Zealand, which were traditionally embedded in discourses of collective democracy, equity and social justice.
\end{abstract}

\section{Keywords}

discourses, early childhood education, neo-liberalism, New Zealand, post-structuralism, professionalism, teacher professional identities 


\section{Introduction}

Over the last two decades, the landscape of early childhood education (ECE) in New Zealand and internationally has been transformed through an ideological shift from a welfare state model to a global neoliberal model in the governance of public sector organisations (May, 2019; Osgood, 2006b; Smith et al., 2016; Woodrow and Press, 2017). The shift has been driven by an 'economist rationalism' mindset (Sumsion, 2006), assuming that neoliberal agendas such as privatisation, deregulation and competition can always, at least in principle, provide better outcomes than states and governments (Codd, 2008; Smith et al., 2016).

By applying a business-management model (Hood, 1991) in ECE, individualistic and competitive entrepreneurialism and financial savvy have become new hallmarks of professionalism and what it means to be an early childhood teacher (Gibson et al., 2015; Osgood, 2006a). Such, so-called managerial (organisational) professionalism (Evetts, 2011; Sachs, 2003) has been demonstrable through teachers' alignment with explicit auditing and accounting organisational principles and commitment to contributing to corporate goals of their ECE organisations. The control of the efficacy of teachers' 'business performance' has been reinterpreted as "the promotion of [their] professionalism" (Evetts, 2011: 412). Consequently, once public servants, teachers have thus become the "subject[s] to market discipline" (Apple, 2005: 12); "employees" producing profits for their business-owners and investors.

In the context of New Zealand, managerial professionalism and business-focused professional identities have been reinforced through radical changes in the country's directives to ECE, especially from 2008 onwards. From an increasingly supportive approach providing 20 hours-a-week free early childhood to all three and four-year-old children in teacher-led ${ }^{1}$ services, New Zealand has swung towards a free-market approach to ECE. The latter approach included policy directives allowing both community-owned and private forprofit services $^{2}$ to access and compete over Government funding for the services' capital

\footnotetext{
${ }^{1}$ Teacher-led services are overseen by a registered and qualified teacher, and are required to meet set registered teacher qualification criteria (Education Council, 2017; Ministry of Education, 2009).

${ }^{2}$ According to the Ministry of Education classification of the service ownership, "community-based" services are owned by an incorporated society, a charitable trust, a statutory trust, a government department, a health board, a local authority, a trading enterprise, a public education institution, the Crown (Education in New Zealand, 2018). Services in "private ownership" are owned by a sole teacher, a company, a partnership, a private trust, or a state-owned enterprise (Education in New
} 
works (Ministry of Education, 2013). With the market, taking control over who provides ECE services, to whom and how seeds of managerial forms of professionalism and ways of being an early childhood teacher were planted.

This article explores the construction of "business-managers" in New Zealand ECE, which emerged through the country's neoliberal agenda reinforcing privatisation, deregulation and competition in the sector. It draws on data originating from my study on how teachers' professional identities have been (re)constructed in response to the shifting discourses in New Zealand ECE over the last two decades (Kamenarac, 2019). The article contributes to the national and international debate on teachers' work and subjectivities (Gibson et al., 2015; Osgood, 2012; Woodrow and Press, 2017). It provokes the ECE sector to consider: How has the construction of teachers as 'business-managers' been legitimised in the thriving neoliberal ECE environments, and what is left unproblematic in the identity constructions on offer? Before addressing these questions, I outline the conceptual framework and research design of my study.

\section{Conceptual and theoretical framework}

To map a theoretical and conceptual terrain for understanding main reference points (i.e. theoretical concepts) of this research, I draw on fundamental assumptions about language, meaning and subjectivity shared by feminist poststructuralists, including Weedon (1997), Bacchi (1999; Bacchi and Goodwin, 2016), and Baxter (2003). Feminist poststructuralism is considered a good fit for the study's purpose because it allows multiple constructions of teacher subjectivities to be explored through "a whole range of discursive practices economic, social and political - the meanings of which are a constant site of struggle over power" (Weedon, 1997: 21). It supports an examination of the potential of discourses and actions associated with "masculinist neo-liberal policy reforms" (Osgood, 2006a: 7) to generate disciplinary powers over teachers in ECE (who are predominantly women), and thus force them to construct particular ways of being (i.e. business-focused, neoliberal professionals) and doing an ECE project.

The main reference points of the study's conceptual and theoretical framework include the concept of discourse, professional identities, professionalism and the New Zealand ECE

Zealand, 2018). 
context, and as such offer a platform for understanding the central research phenomenon teacher professional identities. As illustrated in Figure 1, each reference point informs, builds and impacts on the others, while the concept of discourse, like a thread, connects all reference points. An explanation of each reference point will follow.

\section{Discourse}

The first reference point - the concept of discourse is grounded in the poststructuralist notion of language as a site for the construction and contestation of social meanings and social realities (Baxter, 2003; Weedon, 1997). From a poststructural stance, written and spoken language does not merely describe 'a real' world as it is. Instead, language produces ways of knowing the world and being particular kinds of a subject ('a provisional being') in the world (Bacchi and Goodwin, 2016). In my study, language is considered as a location in which actual and possible ways of being a teacher are constructed, and as a constitutive force, producing particular views of a purpose of ECE. Discourse is identified through a corpus of statements/language constructions used to position and constitute the subjects (i.e. teachers) and objects (i.e. professional identities) of which they speak.

Figure 1. The conceptual and theoretical framework (Kamenarac, 2019, p. 9)

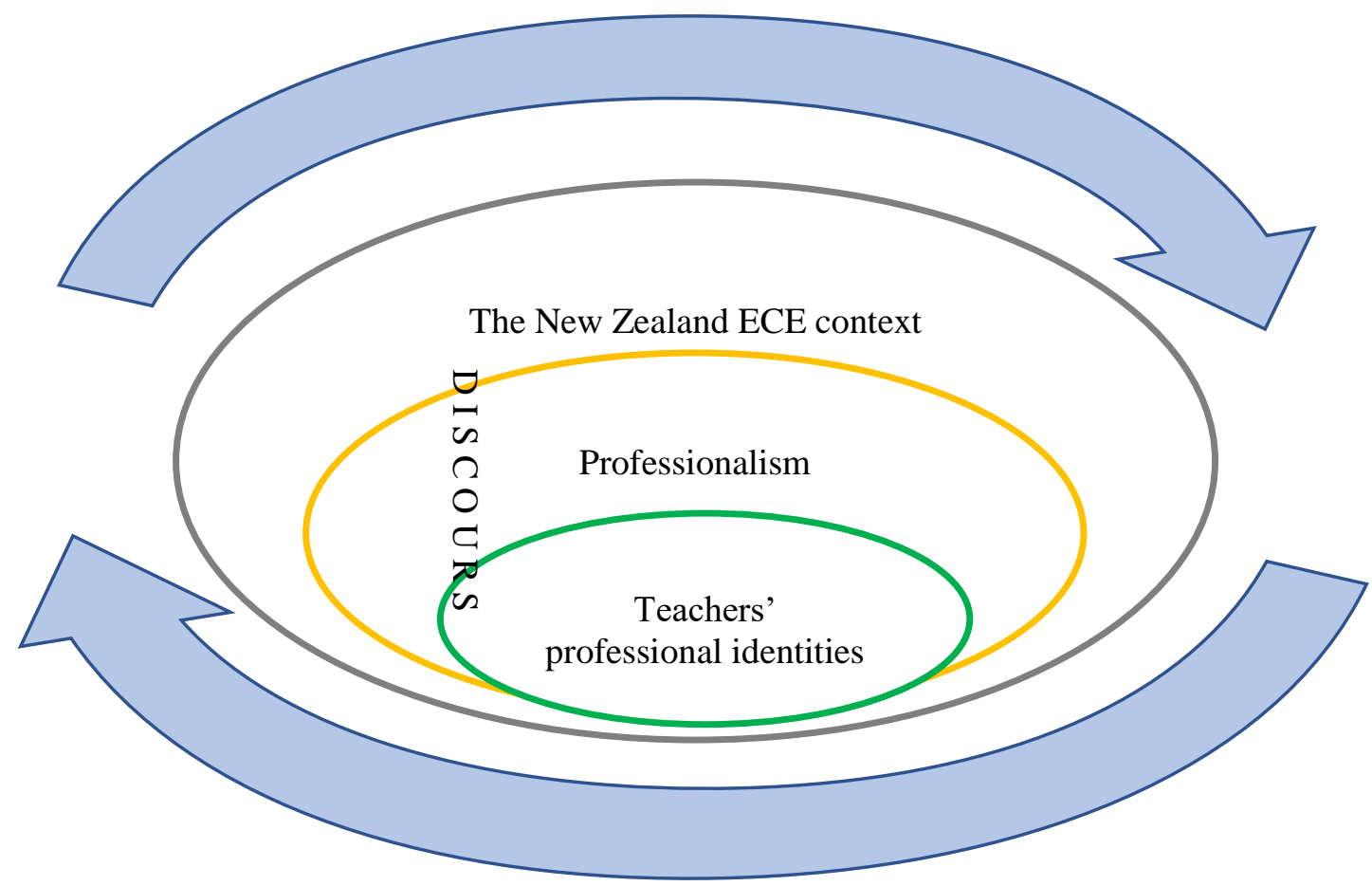




\section{Teachers' professional identities}

The second reference point - the concept of teachers' professional identities draws on the notions of subject and subjectivities as an ever-shifting and evolving phenomenon (Weedon, 1997; Zembylas, 2005). The process of constructing professional identities comes about "from an active engagement with and negotiation of the discourses [embedded in the social structures] through which [teachers] are shaped and in which they are positioned" (Osgood, 2006a: 7). Discourses, thus set 'the conditions of multiple possibilities' (Foucault, 1972) for teachers to construct ideas of "how to be", "how to act" and "how to understand their place [subject positioning] in society" (Sachs, 2005: 15). In this manner, neoliberal discourses may hold power to construct the subjects and subjectivities, and yet the power is not reducible to only one source (e.g. policies, ECE organisations). The produced subjects and subjectivities are instead implicated in power relations, which exist in a dynamic of control, compliance and resistance between discourses and the subjects (Weedon, 1997).

\section{Professionalism}

Teachers' professional identities are further associated with the concept of professionalism (the third reference point). Through a poststructuralist lens, professionalism is viewed as always under re-construction, shifting and evolving in response to changing discourses and conditions in society, public and policy debates and the scholarly arena (Dalli et al., 2012; Grey, 2012; Osgood, 2006a). As such, professionalism is an area of constant struggle over meaning among various parties involved (e.g. the country, teaching professionals, the public).

This article illustrates a form of managerial (organisational) professionalism, which is grounded in the 'smart technologies' of the market (Ball, 2003), underpinning the country's neoliberal agenda to ECE. By reinforcing enterprise, competition and individualisation, managerial professionalism weakens the notion of professionalism that comes from within the profession and recognises the ethical, emotional, relational and political aspects of teachers' work (Campbell-Barr, 2018; Dalli et al., 2012; Osgood, 2012). Moreover, it overpowers democratic (occupational) professionalism and professional identities, once embedded in "collegial authority", "autonomy", "discretionary judgment", "trust and confidence" (Evetts, 2011: 411) and alliances across the sector (Sachs, 2003). 


\section{The New Zealand ECE context}

The fourth reference point - the New Zealand ECE context offers a foundation for understanding teachers' work, identities and professionalism. Hence, it is essential to consider that the country is not a provider of ECE services, and governments have never had a direct role in fully supporting ECE. Instead, the services are a mix of community and private ownership.

Distinctions in the use of funding between private and community-owned services are crucial for understanding teachers' positioning within New Zealand ECE. Private services can make financial gains and distribute these to their members. Community-based services are, however, prohibited from making and distributing financial gains to their members (Education in New Zealand, 2018). Besides, community-owned services are obliged to provide a detailed financial report to the Ministry of Education with a full statement of financial performance, including their profit, loss and balance sheet (Mitchell, 2017). Forprofit services need to provide only an individual financial report on how funding received from the Ministry of Education is spent (Mitchell, 2017). Their other profit-makings (e.g. fees charged from parents) remain out of the Ministry's control.

With the only differentials in funding between community-owned and private for-profit services being removed, the imbalance between these services has increased. In 2018, licensed education and care centres represented $61 \%$ of the entire sector, with 73 percent being in private ownership (Education Counts, 2018). Since, the model of market-based provision did not deliver equitable access to ECE, particularly not in low-income communities (Ritchie et al., 2014), the services' cost has remained the main barrier to the ECE participation (Mitchell et al., 2016). Under pressure to compete to secure the financial viability of their organisations, teachers were forced to favour for-profit interests over the needs of children and families and adopt managerial professionalism and professional identities.

\section{Methodology}

The primary study offered analytical insights into multiple identity constructions of teachers, by undertaking a discourse-analysis of key New Zealand ECE policy documents, group and individual interviews with participants in teaching and leadership positions in ECE settings/organisations (Kamenarac, 2019). This article mainly draws on data gathered through 
one interview with a teacher Karla, which offered a specific insight into the construction of a teacher as "a business manager" in a for-profit ECE setting.

\section{Research participant and research setting}

The primary study involved 24 participants - 14 teachers and 10 participants in a leadership position. Participants were all qualified and fully registered teachers in teacher-led services in New Zealand. Most of the participants (23) were females from diverse ethnic backgrounds, working between 16 and 25 years in community-owned early childhood services.

From the total sample of seven teachers working in for-profit early childhood services, one teacher was purposefully chosen for an individual interview, because of her extensive teaching experience in the for-profit part of the sector. Karla started her teaching career in 2010, at the time of the National Government's neoliberal reform leading to the sector's privatisation and marketisation (May, 2014; Mitchell, 2017). Since then, her work experiences were associated only with one of the largest for-profit ECE organisations in the country. Karla's centre was located in a low socioeconomic community in an urban area, with families who often could not afford to pay for-profit service fees.

Taking into account Karla's rich insights into the for-profit part of the sector, I made an intentional and deliberate choice in selecting Karla for the individual interview. Drawing on the specificity of her teaching experience, Karla's perspectives of teacher identities differed from the accounts of other participants, especially those working in community-owned services before 2010, which additionally strengthened the reasoning behind the purposive sampling.

\section{Research methods of data collection and analysis}

The primary study was undertaken with the University of Waikato's ethics approval. Detailed information on the undertaken ethical procedures, protecting the participants' rights and privacy, are openly available with research findings in the University of Waikato Research Commons website ${ }^{3}$.

The study encompassed three data sets in the form of written and spoken texts. The first data set included eight New Zealand policies regulating the sector over the last two decades (e.g.

\footnotetext{
${ }^{3}$ See https://hdl.handle.net/10289/12363
} 
the curriculum, assessment for learning, self-review guidance, service regulations, professional code and standards in teaching). The policy analysis informed the development of booklets - textual materials with quotations from the policy documents, which were used to provoke the group discussions with participants (Kamenarac, 2019).

The second data set included transcripts from five audio-recorded group interviews with four to six participants in each. Snowball sampling strategy was applied to access 'informationrich' key participants (Bryman, 2012). The group interviews lasted for 80, 100 or 120 minutes and were held at the University of Waikato or participants' workplace. I (the researcher) used an interview protocol with open-ended questions to prompt discussions about issues arising from the policy analysis (e.g. ECE privatisation and marketisation), and their impacts on teachers' work (Kamenarac, 2019).

The third data set included individual interviews with five teachers and three professional leaders/managers. The interview participants were selected from the group interviews based on specified criteria, such as willingness to participate, experiences and knowledge about ECE policies. The interviews were conducted eight to ten months after the group interviews. Before interviewing, participants received a protocol with indicative questions provoking further conversations about issues arising from the group interviews (Kamenarac, 2019).

\section{Analysis}

A discourse-analysis was developed for the specific purpose of the study and was utilised in the analysis of all three data sets (i.e. policy documents, individual and group interviews). The approach enabled the exploration of identity constructions at two levels-within the national policy documents (the macro-level analysis) and actual institutional practices (the micro-level analysis).

The discourse-analysis approach consisted of four interrelated steps, informing, complementing, and overlapping with one another. The analytic steps were: 1) identification of discourses 2) description of teachers' locations within discourses (subject positions) 3) interpretation of possible ways of being a teacher (identity constructions) 4) problematisation of identity constructions of teachers. In the centre of the approach were also two analytic tools. First, the Subject Positioning Tool allowed the identification of teachers' location in the discourse, and second, the Identity Construction Tool uncovered how identity constructions came into existence (Kamenarac, 2019; Gee, 2014; Weedon, 1997). The use of analytic tools 
was accompanied by sets of questions informed by Bacchi's (1999) What is the problem? Approach serving to problematise the identity constructions on offer. A summary of the discourse-analysis approach is offered in Table 1.

Table 1 Discourse-analysis approach and analysis process

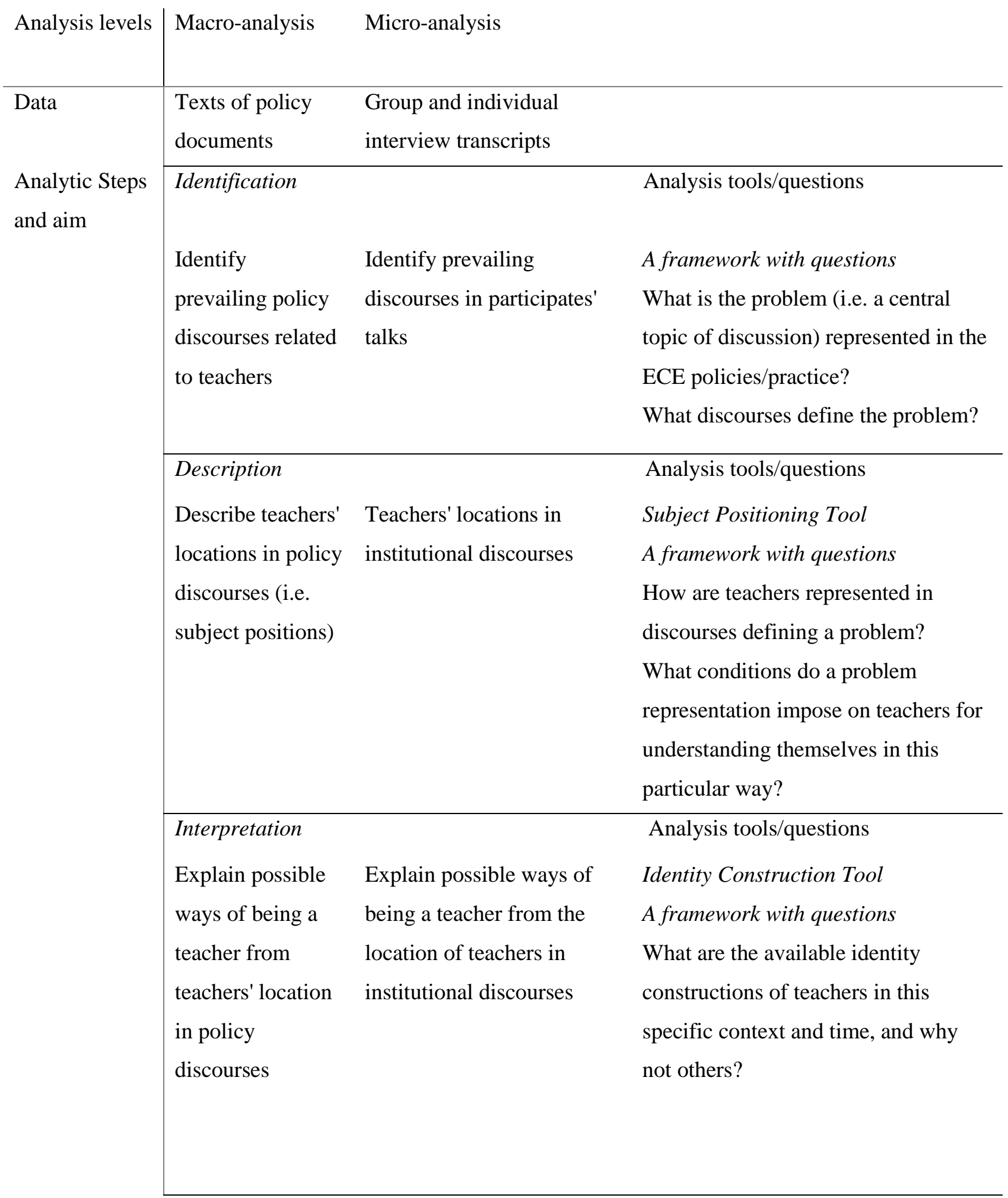


What identity constructions teachers accept/reject and/or negotiate and why?

\section{Problematisation}

Problematise identity

constructions and their effects

\author{
Analysis tools/questions \\ A framework with questions \\ What identities are legitimised in the \\ ECE policies and settings, and why? \\ What are the effects of identity \\ constructions on ECE? \\ What is left unproblematic in the \\ identity constructions on offer, and \\ why?
}

\section{Study's limitations and validity}

Given the small scope of the data and the subjective nature of the discourse-analysis approach, I resist any claim that my findings aim to discover 'truths' ('real facts') about teachers' identities. Various strategies, however, were applied to secure the credibility of description and interpretation of participants' accounts, data analysis and presentation and conclusions (Maxwell, 2013; Tracy, 2010).

For instance, the study combined three different data sets, three methods, and two analysis levels. Richardson (1998: 522) describes such a validity practice as "crystallisation", since it enables a researcher to approach the world from multidimensional "arrays, casting off in different directions", and giving more credibility to a conclusion than just one source and/or method. In addition, interview participants were invited to check and validate interview transcripts, add information contributing to a deeper understanding of the gathered data, ask questions and comment on initial analysis. Lastly, my self-reflexivity was an important contributor to research rigour. It allowed me to take time to access and critically reflect on how my 'brought' and 'research-based selves' (Reinharz, 1997) informed and shaped the 
research processes, procedures and outcomes as well as my relationships with research participants.

\section{Findings}

Here, I draw on group interviews with teachers and managers and an individual interview with a teacher Karla to illustrate the construction of teacher as "a business-manager" in a thriving neoliberal context of New Zealand ECE. First, I present how neoliberal policies created a fertile ground for managerial professionalism and identities to emerge in ECE. Second, I exemplify an interplay of enterprise discourses, underpinning the business operation of Karla's organisation, and democratic discourses, driving Karla's desire to support children and families who cannot afford to pay fees. Lastly, I examine the power of enterprise discourses to limit Karla's agency, and force her to adopt managerial professionalism and embody business-focused identities.

\section{Re-constructing early childhood teachers into "business managers"}

In focus groups with teachers (in text, FG1 ECT) and managers (in the text, FG2 ECM), much time was devoted to considering policy changes in ECE from 2008 to 2017.

Participants illuminated that a view of ECE as "a child's universal right" shifted to "a commodity" that was "traded like goods to those customers who can afford it" (FG1 ECT). The shift happened through policy directives of the National Government, allowing ECE services to ask families for "voluntary donations" and "optional charges" ${ }^{4}$. The ability to ask for "the optional charges" seemed to encourage some business-owners to pressure families to pay "the extra hours of ECE" (FG1 ECT, FG2 ECM) from which they could make a profit. This practice appeared particularly prominent in for-profit ECE settings in low socioeconomic status communities with families with "challenging behaviours", such as "families dealing with drug and alcohol-related issues" and "living in gang communities" (FG1 ECT, FG2 ECM). Participants argued that "to provide adequate service that supports these children to learn basic hygienic habits", "develop social competences" and "basic

\footnotetext{
4 The optional charges are "a payment that parents may choose whether or not to make for a specific purpose"; e.g. excursions, transport, food (Ministry of Education, 2016: 9). Still, ECE services were prohibited from charging 20 hours of ECE service, provided free to all three and four-year-olds by the Government.
} 
communication skills", the children "needed to be longer than 20 hours in their centres" (FG1 ECT, FG2 ECM). However, parents in these local communities often could not afford to pay the extra hours of ECE service, which hindered the centres' profit-making.

Consequently, teachers and managers became forced "to juggle between a business and social side of [their] job" (FG1 ECT, FG2 ECM). Echoing enterprise discourses, underpinning the "business operation" of their organisations, participants "needed to make the profit in their centres, because it is how the business works" (FG1 ECT). On the contrary, the "social side" of their "job" called on discourses of democratic ECE, from which teachers "were obliged to help families who cannot afford to pay the extras" and "support [their] children" (FG2 ECM). Given the tensions between the "social" and "business" side of the "job", teachers needed to "wear two hats" and "juggle between being teachers and business managers" (FG1 ECT). Following the group discussion, the positioning of teachers was further explored in the individual interview with a teacher Karla (in text, IK). Below, Karla examines the construction of teachers as 'business managers" and its shaping on teachers' identities and views of professionalism.

\section{"Always juggling the business and social side of the job" and "wearing two hats"}

Karla described her "company" as "very good in giving money to centres to support children's learning" (IK). Yet she admitted, "the pressure from the business side to make the profit was still evident in teachers' work" (IK). The "pressure" referred to "demands to meet a pre-set target for the number of enrolled children" and "ensure enough money was earned from charging the extra hours to support [the company's] profit-making" (IK). On top of accomplishing the "business demands", teachers also needed to perform tasks related to "the social side of their job", including "supporting children's learning and development", "building relationships with parents and children", and "showing empathy for families' difficult living circumstances" (IK). To perform "both sides of the job", teachers were under a constant pressure to "wear two hats" - "one hat to be teachers and another hat to be the business managers", which Karla explained as follows:

When I am on the floor, I am teaching, but in the back of my head, I am also thinking ... 'how this is going to impact on our business?' I am always juggling. Every decision that I make on the floor must relate to the business side. (IK) 
The metaphor "two hats" illustrated an interplay of enterprise discourses, underpinning the business operation of Karla's organisation, and democratic discourses, driving Karla's desire to support more children and families than her business-owner may allow. While Karla's experience complemented the accounts shared in the focus groups (FG1 ECT, FG2 ECM), it further illuminated the complexity of "juggling [act] between the business and social side of [teachers'] job" in a for-profit ECE setting. Karla revealed that teachers "must" wear the "business hat" in "every decision" they make in their work. The use of business principles in her decision-making was justified with an argument that "teachers need to accept that the first and foremost [ECE] is a business" and "to be able to provide best for children's learning, teachers need to support [the company's] business running" (IK). By seeing ECE as a business, the positioning of teachers as "business managers", who are obliged to comply with and to enact the business principles, was legitimised in Karla's organisation. Moreover, it was normalised that "no matter how much teachers want to get more resources for children" and "push the budget confines", they need to accept

\footnotetext{
there are things that you cannot do, no matter how much you want to .... You cannot really do like, 'Ok, I really felt that children needed this, and I am going to spend \$300' when you do not actually have it .... You are going to be told 'That was not in your budget. You should not be spending that'. You do have these restrictions, and you need to make those decisions, like 'Ok, we cannot do that'. (IK)
}

Furthermore, Karla's statement illustrated the power of enterprise discourses to limit teachers' agency for making informed and independent decisions in their teaching. It alluded that the "business principles" served as a mechanism for strengthening teachers' cost-conscious mentality and securing their commitment to the company's principles driving its profitmaking. With this said, it is important to note not that participants from other services did not have restrictions on what they could spend. Instead, the statement showed that in the business ECE organisations, enterprise discourses might constrain more severely teachers' work, agency and identities.

\section{"Knowing both sides of the job"}

Given the complexity in performing "the business" and "social side" of the "job", one may ask how teachers get ready to wear both hats. To address this question, next, Karla discussed 
the importance of specialised knowledge that teachers need to acquire to understand "both sides of the job".

..... Teachers [need] to start learning from very early about the business side of their job. They need to understand why they get the answer 'No, you cannot do it'... [Teachers] need to understand there are restrictions in the business that restricts the learning, and that is just the way this business goes. You cannot expect that you will be given everything if you are not making money in your centre. You have to learn how to make the profit ... (IK)

Karla's statement echoed that learning about how to "support the business operation of the centre by making money" (IK) is crucial in her work. The specialised learning aimed to equip her with the knowledge necessary for "keep[ing] the full occupancy", "welcoming new parents, showing them around" and "form[ing] relationships ... as soon as they walk into that door ..." (IK). While quality relationships are crucial for quality teaching in ECE (Education Council, 2017), the emphasis on "forming relationships" with "new parents as soon as they walk into the centre" makes one wonder whether these, at first sight, ordinary cordialities were marketing tools for "keeping families into the centre" (IK). The feeling of doubt was further fuelled with Karla's statement that "the company always provides professional development for doing the business" and "teachers can always count on business people from the company to teach them about all the aspects of the business" (IK). On this ground, I argue that by providing "adequate business development" established upon the enterprise principles and specialised business knowledge, the organisation reinforced managerial professionalism in Karla's work. Moreover, it secured Karla's commitment to the company's profit targets and performance indicators while forcing her to adopt managerial professionalism and professional identities. At the same time, however, the company limited Karla's agency to make informed and independent professional decisions that are aligned with the principles of the professional ethics - formerly one of the key characteristics of teachers' work and democratic professionalism (Evetts, 2011; Sachs, 2003).

\section{Discussion and conclusion}

The discussed research findings complement the literature about business style managerialism in education and confirm the growing concerns about the power of the business management expertise in transforming democratic teaching practices and 
professionalism in ECE (Evetts, 2011; Osgood, 2006a; Press and Woodrow, 2005; Sachs, 2003). On this ground, I argue that if left unproblematic, the construction of "business managers" has a powerful potential to overpower teachers identities, once established in democracy, collegiality and advocacy for children, families and communities. I further maintain that such identities could weaken the capacity of teachers to position themselves as advocate-activist professionals (Bown and Sumsion, 2016; Sachs, 2003; Urban, 2012), and construe their work through "a story of democracy, experimentation and potentiality" (Moss, 2014: 2).

While the research data illustrated the power of managerial discourses to shape professional identities and professionalism, nonetheless, it is necessary to highlight that the businessfocused identities are not, and must not be seen as, the only identities emerging in a neoliberal ECE context. Rather than viewing neoliberal discourses only as stumbling blocks, I further propose that it is equally necessary to take the discourses as a starting point for rethinking who we are as ECE educators and re-envisioning whom we would like to be. To turn the challenge into an opportunity, I invite the sector to critically examine opposing strategies that may reassert democratic practices and forms of professionalism in ECE and thus construct and strengthen the advocate-activist teacher identities (Groundwater-Smith and Sachs, 2002).

Although not an easy task in the neoliberal era of ECE, the democratisation project of ECE requires teachers' determination and capacity to choose consciously between conflicting alternatives and taking responsibility for the choices made (Dahlberg et al., 2013; Dahlberg and Moss, 2005). To deliberately resist neoliberal discourses, teachers must reposition themselves from 'employees' and 'business managers' into advocate-activist teachers (Kamenarac, 2019), and from the new positioning, deliberately construct their professional identities. The advocate-activist teacher identities need to be established in the ethics of resistance which position teachers individually and collectively as ethically obliged to continually re-examine and disrupt discourses driving their work, decision-making and professional identities (Lenz-Taguchi, 2008). By building the capacities for practising the ethics of resistance, teachers can critically engage with neoliberal discourses and create alternatives that show that it is possible to think, be and act differently and that the businessfocused identities and managerial professionalism are a choice, not a necessity. 


\section{Acknowledgement}

I would like to express my gratitude to teachers who participated in my research study, and willingly and enthusiastically debated the issues presented in this article. My special thanks go to two reviewers for their helpful comments that led to improvement of an earlier draft of the article.

\section{Funding}

The authors received no financial support for the research, authorship, and/or publication of this article.

\section{Disclosure statement}

The author reported no potential conflict of interest.

\section{References}

Apple MW (2005) Education, markets, and an audit culture. Critical Quarterly 47(1-2): 1129. DOI: 10.1111/j.0011-1562.2005.00611.x.

Bacchi C (1999) Women, Policy and Politics: The Construction of Policy Problem. Available at: http://site.ebrary.com (accessed 11 August 2014).

Bacchi C and Goodwin S (2016) Poststructural Policy Analysis. New York, NY: Palgrave Macmillan US. DOI: 10.1057/978-1-137-52546-8.

Ball S (2003) The teacher's soul and the terror of performativity. Journal of Education Policy 18(2): 215-218. DOI: https://doi.org/10.1080/0268093022000043065.

Baxter J (2003) Positioning Gender in Discourse: A Feminist Methodology. New York, NY: Palgrave Macmillan.

Bown K and Sumsion J (2016) Generating visionary policy for early childhood education and care: Politicians' and early childhood sector advocate/activists' perspectives. Contemporary Issues in Early Childhood 17(2): 192-209. DOI: 10.1177/1463949116641511.

Bryman A (2012) Social Research Methods. 4th ed. Oxford, England: Oxford University Press.

Campbell-Barr V (2018) The silencing of the knowledge-base in early childhood education and care professionalism. International Journal of Early Years Education 26(1): 7589. DOI: 10.1080/09669760.2017.1414689. 
Codd J (2008) Neoliberalism, globalisation and the deprofesionalisation. In: Carpenter V, Jesson J, Roberts P, et al. (eds) Nga Kaupapa Here: Connections and Contradictions in Education. Melbourne, Australia: Cengage Learning, pp. 14-24.

Dahlberg G and Moss P (2005) Ethics and Politics in Early Childhood Education. London, UK: Taylor and Francis.

Dahlberg G, Moss P and Pence A (2013) Beyond Quality in Early Childhood Education and Care: Languages of Evaluation. 3rd ed. London, UK: Routledge.

Dalli C, Miller L and Urban M (2012) Professionalism in local and cross-national contexts: Towards a critical ecology of the profession. In: Miller L, Dalli C, and Urban M (eds) Early Childhood Grows up: Towards a Critical Ecology of the Profession. 1st ed. International perspectives on early childhood education and development. Dordrecht, The Netherlands: Springer, pp. 3-19.

Education Council (2017) Our Code Our Standards. Code of Professional Responsibility and Standards for the Teaching Profession. Wellington, New Zealand: Author.

Education Counts (2018) Early childhood services. Available at: https://www.educationcounts.govt.nz/data-services/directories/early-childhoodservices (accessed 21 July 2018).

Education in New Zealand (2018) The different early learning service types. Available at: https://www.education.govt.nz/early-childhood/running-a-service/starting-aservice/where-to-begin/ (accessed 21 July 2018).

Evetts J (2011) A new professionalism? Challenges and opportunities. Current Sociology 59(4): 406-422. DOI: 10.1177/0011392111402585.

Foucault M (1972) The Archaeology of Knowledge (tran. SAM Smith). World of man. New York, NY: Pantheon. (Original work published in 1969).

Gee JP (2014) How to Do Discourse Analysis: A Toolkit. 2nd ed. Milton Park, Abingdon, Oxon: Routledge.

Gibson M, McArdle F and Hatcher C (2015) Governing child care in neoliberal times: Discursive constructions of children as economic units and early childhood educators as investment brokers. Global Studies of Childhood 5(3): 322-332. DOI:

$10.1177 / 2043610615597149$.

Grey A (2012) The inside-out professional: A framework for reflection and practice. Early Education 52, Spring/Summer: 9-12.

Groundwater-Smith S and Sachs J (2002) The activist professional and the reinstatement of trust. Cambridge Journal of Education 32(3): 341-358. DOI:

10.1080/0305764022000024195.

Hood C (1991) A public management for all seasons? Public Administration 69(1): 3-19. DOI: $10.1111 /$ j.1467-9299.1991.tb00779.x. 
Kamenarac O (2019) Discursive constructions of teachers' professional identities in early childhood policies and practice in Aotearoa New Zealand: Complexities and contradictions. PhD Thesis, University of

Waikato, Hamilton, New Zealand. Available at: https://hdl.handle.net/10289/12363

Lenz-Taguchi H (2008) An 'ethics of resistance' challenges taken-for-granted ideas in Swedish early childhood education. International Journal of Educational Research 47(5): 270-282. DOI: https://doi.org/10.1016/j.ijer.2008.12.006.

Maxwell JA (2013) Qualitative Research Design: An Interactive Approach. 3rd ed. Applied social research methods series 41. Thousand Oaks, CA: Sage Publications.

May H (2014) New Zealand: A narrative of shifting policy directions for early childhood education and care. In: Gambaro L, Stewart K, and Waldfogel J (eds) An Equal Start? Providing Quality Early Education and Care for Disadvantaged Children. Bristol, UK: Policy Press, pp. 147-170.

May H (2019) Politics in the Playground: The World of Early Childhood in Aotearoa New Zealand. (Revised edition 2019. ed.). Dunedin, New Zealand: Otago University Press.

Ministry of Education (2009) Teacher-led services. Available at: http://www.minedu.govt.nz/Parents/EarlyYears/HowECEWorks/TypesOfECEService /TeacherLedService.aspx (accessed 30 December 2014).

Ministry of Education (2013) ECE participation programme. Available at: https://www.educationcounts.govt.nz/publications/ECE/ece-participation-programmeevaluation (accessed 7 January 2015).

Mitchell L (2017) Discourses of economic investment and child vulnerability in early childhood education. Waikato Journal of Education 22(1). DOI: 10.15663/wje.v22i1.552.

Mitchell L, Meagher-Lundberg P, Arndt S, et al. (2016) ECE Participation Programme evaluation. Stage 4. Report to the Ministry of Education. New Zealand: Ministry of Education.

Moss P (2014) Transformative Change and Real Utopias in Early Childhood Education: A Story of Democracy, Experimentation and Potentiality. London, UK: Routledge.

Osgood J (2006a) Deconstructing professionalism in early childhood education: Resisting the regulatory gaze. Contemporary Issues in Early Childhood 7(1): 5. DOI: 10.2304/ciec.2006.7.1.5.

Osgood J (2006b) Professionalism and performativity: The feminist challenge facing early years practitioners. Early Years 26(2): 187-199. DOI: 10.1080/09575140600759997.

Osgood J (2012) Narratives from the Nursery: Negotiating Professional Identities in Early Childhood. New York, NY: Routledge. 
Press F and Woodrow C (2005) Commodification, corporatisation and children's spaces. Australian Journal of Education 49(3): 278-291. DOI: 10.1177/000494410504900305.

Reinharz S (1997) Who am I? The need for a variety of selves in the field. In: Hertz R (ed.) Reflexivity and Voice. Thousand Oaks, CA: Sage Publications, pp. 3-30.

Richardson L (1998) Writing a method of inquiry. In: Denzin NK and Lincoln YS (eds) Handbook of Qualitative Research. Thousand Oaks, CA: Sage Publications, pp. 516529.

Ritchie J, Harvey N, Kayes M, et al. (2014) Early childhood care and education, and child poverty. In: Dale CM, 'O'Brien M, and St John S (eds) Our Children, Our Choice: Priorities for Policy. Part Two. Child Poverty Action Group Policy Paper Series. Part Two: Early Childhood Care \& Education (ECCE). Auckland, New Zealand: Child Poverty Action Group, pp. 1-15.

Sachs J (2003) The Activist Teaching Profession. Buckingham, Philadelphia: Open University Press.

Sachs J (2005) Teacher education and the development of professional identity: Learning to be a teacher. In: Denicolo P and Kompf M (eds) Connecting Policy and Practice: Challenges for Teaching and Learning in Schools and Universities. Oxford, England: Routledge, pp. 5-21.

Smith K, Tesar M and Myers CY (2016) Edu-capitalism and the governing of early childhood education and care in Australia, New Zealand and the United States. Global Studies of Childhood 6(1): 123-135. DOI: 10.1177/2043610615625165.

Sumsion J (2006) From Whitlam to economic rationalism and beyond: A conceptual framework for political activism in children's services'. Australian Journal of Early Childhood 31(1): 1-9.

Tracy SJ (2010) Qualitative quality: Eight "big-tent" criteria for excellent qualitative research. Qualitative Inquiry 16(10): 837-851. DOI: 10.1177/1077800410383121.

Urban M (2012) The uncertain expert: A case study from Germany. In: Miller L, Dalli C, and Urban M (eds) Early Childhood Grows up: Towards a Critical Ecology of the Profession. International perspectives on early childhood education and development. Dordrecht, The Netherlands: Springer, pp. 71-85.

Weedon C (1997) Feminist Practice and Poststructuralist Theory. 2nd ed. Cambridge, MA: Blackwell.

Woodrow C and Press F (2017) The privatisation/marketisation of ECEC debate: Social versus neoliberal models. In: Miller L, Cameron $\mathrm{C}$, Dalli C, et al. (eds) The Sage Handbook of Early Childhood Policy. London, England: Sage, pp. 537-550.

Zembylas M (2005) Discursive practices, genealogies, and emotional rules: A poststructuralist view on emotion and identity in teaching. Teaching and Teacher Education 21(8): 935-948. DOI: 10.1016/j.tate.2005.06.005. 
